\title{
$\left({ }^{\mathrm{A}} \gamma \delta \beta\right)^{\circ}$-Thalassaemia in Blacks is due to a deletion of $34 \mathrm{kbp}$ of DNA
}

\author{
P. S. Henthorn, O. Smithies, T. Nakatsuji, ${ }^{*}$ A. E. Felice, ${ }^{*} \dagger$
}

M. B. GARdiner, ${ }^{*}$ A. L. ReESE* AND T. H. J. Huisman*† Laboratory of Genetics, University of Wisconsin, Madison, WI 53706, *Department of Cell and Molecular Biology, Medical College of Georgia, Augusta, GA 30912, and †Hemoglobin Research Laboratory, Veterans Administration Medical Center, Augusta, GA 30910, U.S.A.

Received 26 March 1984; accepted for publication 1 July 1984

SUMMARY. DNA from members of 10 Black families with conditions considered to be ${ }^{\mathrm{G}} \gamma(\delta \beta)^{\circ}$-thalassaemia or ${ }^{\mathrm{G}} \gamma(\delta \beta)^{\circ}$-HPFH were studied by using restriction enzyme analysis. One or more affected members from each family were shown to have the same deletion of $34 \mathrm{kbp}$ of DNA in the human $\beta$-globin gene cluster. A clone spanning the deletion was isolated from the DNA of one such person and studied in detail. The deletion removed part of the ${ }^{\mathrm{A}} \gamma$ and all of the $\psi \beta, \delta$ and $\beta$-globin genes and is different from the four previously identified deletions which caused a condition resently known as $\left({ }^{\mathrm{A}} \gamma \delta \beta\right)^{\circ}$-thalassaemia.

Hereditary persistence of fetal haemoglobin (HPFH) and $(\delta \beta)^{\circ}$-thalassaemia (thal) are heterogeneous conditions which are characterized by absent or decreased synthesis of the $\delta$ and $\beta$ globin of haemoglobins $(\mathrm{Hb})$ and an increased synthesis of the $\gamma$ chain containing fetal $\mathrm{Hb}$. In the heterozygote, an anaemia is usually absent but a mild microcytosis may exist. Homozygotes for $(\delta \beta)^{\circ}$-thal have a thalassaemia intermedia, while HPFH homozygotes might have a slight microcytosis but lack anaemia or clinical consequences of their anomaly (for review and references, see Weatherall \& Clegg, 1981). Most examples of HPFH and $(\delta \beta)^{\circ}$-thal thus far analysed are characterized by deletions of DNA in the $\beta$ globin gene cluster which differ in size and location (Orkin et al, 1979; Mears et al, 1978; Ottolenghi et al, 1979, 1981; Fritsch et al, 1979; Tuan et al, 1979, 1980; Bernards et al, 1979, 1980; Jones et al, 1981a, b; Kutlar et al, 1984).

$\mathrm{G}_{\gamma}$ types of $(\delta \beta)^{\circ}$-thal and $\mathrm{G}_{\gamma}$ types of HPFH have been observed in various populations and are characterized either by absent or decreased synthesis of $\beta$ and $\delta$ chains, increased synthesis of ${ }^{\gamma} \gamma$ chains, and a nearly normal haematology with mild microcytosis in the heterozygote. Several families with heterozygotes for one of these conditions have been observed by some of us among the Black populations of the southeastern U.S.A. Some have Correspondence: Dr Titus H. J. Huisman, Regents' Professor and Chairman, Department of Cell and Molecular Biology, Director, Comprehensive Sickle Cell Center, Medical College of Georgia, Augusta, GA 30912, U.S.A. 
been labelled as ${ }^{G} \gamma-\beta^{+}$-HPFH (Huisman et al, 1975), and others as ${ }^{G} \gamma-(\delta \beta)^{\circ}$-thalassaemia or $\mathrm{G}_{\gamma}$-HPFH (Altay et al, 1977; Boyer et al, 1977). In order to determine whether or not there is a molecular basis for any phenotype differences between such individuals we have initiated a detailed investigation of many of these families using gene mapping and related techniques. The results of this study with individuals previously classified as having ${ }^{\mathrm{G}_{\gamma}}-(\delta \beta)^{\circ}$-thal or $\mathrm{G}_{\gamma}-\beta^{\circ}$-HPFH (Altay et al, 1977) show that all affected subjects have lost their ${ }^{\mathrm{G}} \gamma, \delta$ and $\beta$-globin genes as a consequence of the deletion of the same $34 \mathrm{kbp}$ of DNA.

\section{MATERIALS AND METHODS}

Blood samples. Thirty-one (31) Black subjects from 10 families participated in this study. From each subject, $10-30 \mathrm{ml}$ of blood were collected with EDTA as anticoagulant and transported in ice to the laboratory. Informed consent was obtained prior to collection.

Haematological and haemoglobin analyses. Complete blood counts were obtained with a Coulter Model S cell counter or with a Sysmex CC-720 cell counter. Evaluation of a possible microcytosis and hypochromia was made through examination of blood smears, while the distribution of $\mathrm{Hb} \mathrm{F}$ was studied with the method of Kleihauer et al, as described in Huisman \& Jonxis (1977). Globin chain synthesis studies were performed as previously described (Huisman \& Jonxis, 1977). The presence of $\mathrm{Hb} \mathrm{F}$ and $\mathrm{Hb} \mathrm{S}$ in red cell lysates was demonstrated by cellulose acetate electrophoresis at alkaline $\mathrm{pH}$ and citrate agar electrophoresis at acid $\mathrm{pH}$ (Huisman \& Jonxis, 1977). Hb F was quantitated by alkali denaturation (Betke et al, 1959), and $\mathrm{Hb} \mathrm{A}_{2}$ either by micro- or macro-DEAE-cellulose column chromatography (Abraham $e t$ al, 1976; Schleider et al, 1977). Hb F was isolated by DEAE-cellulose chromatograph: (Schroeder \& Huisman, 1980) and its $\gamma$ chain composition determined by high performance liquid chromatography (HPLC) (Huisman \& Wilson, 1980).

DNA analyses. DNA was prepared from peripheral blood using the method of Poncz et al (1982). Restriction enzyme mapping of genomic DNA was done by previously described methods (Kutlar et al, 1984; Vanin et al, 1983) using the probes $\gamma$ IVS and pRK28. The $\gamma$ IVS probe is a 457 bp Bam HI-Pvu II fragment from the ${ }^{A} \gamma$ globin gene large intervening sequence. The pRK28 probe is a $1 \cdot 1 \mathrm{kbp}$ Eco RI-Sal I fragment from the plasmid pRK28, kindly provided by Dr Russell Kaufman. This probe is located approximately $16 \mathrm{kbp} 3$ ' to the $\beta$-globin gene. The relative number of $\alpha$-globin genes were determined by digesting DNA with Xba I and Bgl II, and hybridizing with an $\alpha$-globin probe derived from plasmid JW101, as described previously (Felice et al, 1982).

A $7 \cdot 8 \mathrm{kbp}$ Eco RI fragment detected in the DNA of patient B.A. using the $\gamma \mathrm{IVS}$ probe was cloned into phage Ch3A $\triangle$ lac by using a size fractionated Eco RI digest $(6 \cdot 0-\mathbf{9} \cdot 0 \mathrm{kbp})$ of genomic DNA from patient B.A. and the procedures of Blattner et al (1978). The resulting phages were screened without amplification with the $\gamma \mathrm{IVS}$ probe. The $7 \cdot 8 \mathrm{kbp}$ insert from a recombinant phage was subcloned into the Eco RI site of plasmid p010 ori (Maeda et al, 1983). The resulting recombinant plasmid and the plasmid pRK20 were mapped with restriction enzymes used under conditions recommended by the manufacturers. The plasmid pRK20 (which contains a 9.3 kbp Bam HI-Eco RI insert of DNA from the region 3' to $\beta$ ) was also kindly provided by Dr Russell Kaufman. 


\section{RESULTS}

\section{The patients}

Table I lists appropriate data for the 31 Black subjects belonging to 10 families. Twenty-four of the subjects were heterozygotes for a condition characterized by variable elevations of $\mathrm{HbF}$,

Table I. Haematological and haemoglobin data

\begin{tabular}{|c|c|c|c|c|c|c|c|c|c|c|c|c|c|}
\hline \multicolumn{2}{|c|}{$\begin{array}{c}\text { Family } \\
\text { and case }\end{array}$} & \multirow{2}{*}{$\begin{array}{r}\begin{array}{r}\text { Sex } \\
\text { age }\end{array} \\
\text { M, } 50\end{array}$} & \multirow{2}{*}{$\begin{array}{c}\begin{array}{c}\mathrm{Hb} \\
\text { type }\end{array} \\
\mathrm{AF}\end{array}$} & \multirow{2}{*}{$\begin{array}{c}\begin{array}{c}\mathrm{Hb} \\
(\mathrm{g} / \mathrm{dl})\end{array} \\
11 \cdot 3\end{array}$} & \multirow{2}{*}{$\begin{array}{c}\begin{array}{c}\mathrm{PCV} \\
(\mathrm{l} / \mathrm{l})\end{array} \\
0 \cdot 345\end{array}$} & \multirow{2}{*}{$\begin{array}{c}\begin{array}{c}\mathrm{RBC} \\
\left(10^{12} / \mathrm{l}\right)\end{array} \\
4 \cdot 83\end{array}$} & \multirow{2}{*}{$\begin{array}{c}\begin{array}{c}\text { MCV } \\
\text { (fl) }\end{array} \\
71\end{array}$} & \multirow{2}{*}{$\begin{array}{c}\begin{array}{c}\mathrm{MCH} \\
(\mathrm{pg})\end{array} \\
23 \cdot 4\end{array}$} & \multirow{2}{*}{$\begin{array}{l}\begin{array}{l}\mathrm{A}_{2} \\
(\%)\end{array} \\
2 \cdot 55\end{array}$} & \multirow{2}{*}{$\begin{array}{l}\begin{array}{l}\mathrm{F}_{\mathrm{AD}} \\
(\%)\end{array} \\
10 \cdot 9\end{array}$} & \multirow{2}{*}{$\begin{array}{c}\alpha / \text { non- } \alpha \\
\text { ratio }\end{array}$} & \multirow{2}{*}{$\frac{\%{ }^{G} \gamma}{93 \cdot 8}$} & \multirow{2}{*}{$\frac{\alpha \text { genes }}{-\alpha / \alpha \alpha}$} \\
\hline W & W.W. & & & & & & & & & & & & \\
\hline & L.W. & F, 25 & SF & $12 \cdot 8$ & 0.376 & $4 \cdot 75$ & 79 & $26 \cdot 9$ & $2 \cdot 3$ & $17 \cdot 3$ & n.d. & $89 \cdot 8$ & $\alpha \alpha / \alpha \alpha$ \\
\hline & S.W. & F, 24 & $\mathrm{AF}$ & $13 \cdot 2$ & 0.400 & $5 \cdot 86$ & 68 & $22 \cdot 5$ & $2 \cdot 25$ & $11 \cdot 6$ & $1 \cdot 73$ & $98 \cdot 5$ & $-\alpha / \alpha \alpha$ \\
\hline & B.W. & M, 21 & $\mathrm{AF}$ & $13 \cdot 7$ & 0.403 & $6 \cdot 63$ & 61 & $20 \cdot 7$ & $2 \cdot 45$ & $6 \cdot 3$ & 1.93 & $90 \cdot 0$ & $\alpha \alpha / \alpha \alpha$ \\
\hline & Ba.W.* & F, 19 & SF & $12 \cdot 8$ & $0 \cdot 376$ & $4 \cdot 75$ & 79 & $26 \cdot 9$ & $1 \cdot 8$ & $17 \cdot 3$ & 0.88 & $89 \cdot 8$ & $-\alpha / \alpha \alpha$ \\
\hline & J.W. & M, 17 & $\mathrm{AF}$ & $15 \cdot 1$ & 0.431 & $6 \cdot 11$ & 71 & $24 \cdot 7$ & $2 \cdot 0$ & $14 \cdot 6$ & $1 \cdot 35$ & $91 \cdot 6$ & $-\alpha / \alpha \alpha$ \\
\hline & A.W.* & $\mathrm{F}, 12$ & SF & $11 \cdot 4$ & $0 \cdot 352$ & $4 \cdot 74$ & 75 & $24 \cdot 1$ & $2 \cdot 0$ & $21 \cdot 0$ & $1 \cdot 71$ & $98 \cdot 9$ & $\alpha \alpha / \alpha \alpha$ \\
\hline \multirow[t]{3}{*}{ A } & M.A. & F, 40 & $\mathrm{AF}$ & $10 \cdot 6$ & 0.337 & $3 \cdot 46$ & 91 & $30 \cdot 6$ & $1 \cdot 8$ & $14 \cdot 5$ & $1 \cdot 85$ & $98 \cdot 8$ & n.d. \\
\hline & B.A.* & $\mathrm{F}, 17$ & SF & $9 \cdot 3$ & $0 \cdot 285$ & $3 \cdot 39$ & 83 & $27 \cdot 4$ & $2 \cdot 3$ & $21 \cdot 6$ & 1.93 & $94 \cdot 8$ & $\alpha \alpha / \alpha \alpha$ \\
\hline & H.A.* & F, 16 & SF & $9 \cdot 2$ & $0 \cdot 273$ & $3 \cdot 55$ & 76 & $25 \cdot 9$ & $2 \cdot 0$ & $19 \cdot 2$ & 1.92 & $95 \cdot 3$ & $\alpha \alpha / \alpha \alpha$ \\
\hline \multirow[t]{6}{*}{$\mathrm{I} / \mathrm{N}^{\prime}$} & R.I.* & F, 45 & $\mathrm{AF}$ & $9 \cdot 8$ & 0.373 & $3 \cdot 89$ & 80 & $25 \cdot 2$ & $2 \cdot 75$ & $16 \cdot 5$ & n.d. & $92 \cdot 8$ & $-\alpha / \alpha \alpha$ \\
\hline & M.I.* & M, 17 & $\mathrm{AF}$ & $12 \cdot 1$ & 0.375 & $4 \cdot 26$ & 88 & $28 \cdot 4$ & $3 \cdot 1$ & $11 \cdot 9$ & 1.09 & $86 \cdot 8$ & $-\alpha / \alpha \alpha$ \\
\hline & J.I.* & M, 15 & $\mathrm{AF}$ & $12 \cdot 6$ & 0.405 & $5 \cdot 13$ & 79 & $24 \cdot 6$ & $3 \cdot 25$ & $8 \cdot 4$ & $1 \cdot 15$ & $86 \cdot 2$ & $-\alpha / \alpha \alpha$ \\
\hline & N.I.* & $\mathrm{F}, 13$ & $\mathrm{AF}$ & $11 \cdot 1$ & 0.325 & $3 \cdot 84$ & 85 & $28 \cdot 9$ & $3 \cdot 05$ & $15 \cdot 1$ & n.d. & $86 \cdot 1$ & $\alpha \alpha / \alpha \alpha$ \\
\hline & F.M. & F, 19 & SF & $10 \cdot 3$ & $0 \cdot 315$ & $3 \cdot 76$ & 82 & $27 \cdot 4$ & $3 \cdot 1$ & $19 \cdot 8$ & n.d. & $92 \cdot 8$ & n.d. \\
\hline & J.S. & F, 37 & SF & $9 \cdot 4$ & $0 \cdot 292$ & $3 \cdot 14$ & 91 & $29 \cdot 9$ & $2 \cdot 5$ & $18 \cdot 3$ & n.d. & $90 \cdot 3$ & n.d. \\
\hline \multirow[t]{5}{*}{$\mathrm{M} / \mathrm{C}$} & W.B.L.* & $\mathrm{F}, 35$ & $\mathrm{AF}$ & $11 \cdot 7$ & 0.375 & $5 \cdot 07$ & 74 & $23 \cdot 4$ & $2 \cdot 3$ & $9 \cdot 3$ & n.d. & $95 \cdot 8$ & $-\alpha / \alpha \alpha$ \\
\hline & J.M.* & M, 15 & $\mathrm{AF}$ & $14 \cdot 7$ & 0.433 & $6 \cdot 12$ & 72 & $24 \cdot 0$ & $2 \cdot 0$ & $12 \cdot 3$ & $0 \cdot 81$ & $91 \cdot 2$ & $-\alpha / \alpha \alpha$ \\
\hline & W.C.C.* & M, 14 & $\mathrm{AF}$ & $13 \cdot 3$ & $0 \cdot 395$ & $6 \cdot 16$ & 66 & $21 \cdot 6$ & $2 \cdot 2$ & $4 \cdot 0$ & $1 \cdot 38$ & $94 \cdot 5$ & $-\alpha / \alpha \alpha$ \\
\hline & J.L.C. & M, 25 & $\mathrm{AF}$ & $14 \cdot 2$ & $0 \cdot 445$ & $6 \cdot 14$ & 74 & $23 \cdot 1$ & $2 \cdot 15$ & $5 \cdot 2$ & n.d. & $92 \cdot 8$ & n.d. \\
\hline & Jl.M. & M, 12 & $\mathrm{AF}$ & $14 \cdot 3$ & 0.423 & $6 \cdot 00$ & 73 & $23 \cdot 8$ & $2 \cdot 1$ & $11 \cdot 8$ & n.d. & $94 \cdot 0$ & n.d. \\
\hline \multirow[t]{2}{*}{$S$} & W.S.* & M, 42 & $\mathrm{AF}$ & $14 \cdot 0$ & $0 \cdot 418$ & 6 & 66 & $22 \cdot 0$ & $1 \cdot 8$ & $9 \cdot 2$ & n.d. & 89.9 & $\alpha \alpha / \alpha \alpha$ \\
\hline & M.S. & M, 19 & $\mathrm{AF}$ & $13 \cdot 6$ & 0.424 & $5 \cdot 56$ & 76 & $24 \cdot 5$ & $1 \cdot 7$ & $8 \cdot 5$ & n.d. & $91 \cdot 9$ & n.d. \\
\hline \multirow[t]{2}{*}{ T-l } & G.T.* & F, 20 & $\mathrm{AF}$ & $11 \cdot 8$ & 0.365 & $4 \cdot 50$ & 81 & $26 \cdot 2$ & $2 \cdot 6$ & $16 \cdot 2$ & & $94 \cdot 6$ & $-\alpha / \alpha \alpha$ \\
\hline & A.T.* & M, 18 & $\mathrm{AF}$ & $14 \cdot 5$ & 0.443 & $5 \cdot 90$ & 75 & $24 \cdot 6$ & $2 \cdot 5$ & $13 \cdot 3$ & & $95 \cdot 0$ & $\alpha \alpha / \alpha \alpha$ \\
\hline W & B.W.* & F, 29 & $\mathrm{AF}$ & $12 \cdot 2$ & $0 \cdot 375$ & $5 \cdot 12$ & 73 & $23 \cdot 8$ & $2 \cdot 5$ & $12 \cdot 7$ & $1 \cdot 25$ & $87 \cdot 0$ & $\alpha \alpha / \alpha \alpha$ \\
\hline G & L.G.* & $\mathrm{F}, 21$ & $\mathrm{AF}$ & $10 \cdot 8$ & $0 \cdot 320$ & $3 \cdot 94$ & 81 & $27 \cdot 4$ & $2 \cdot 5$ & $15 \cdot 0$ & $1 \cdot 34$ & $94 \cdot 9$ & $\alpha \alpha / \alpha \alpha$ \\
\hline \multirow[t]{3}{*}{$\mathrm{T}-2$} & M.T.* & F, 31 & $\mathrm{AF}$ & $10 \cdot 7$ & $0 \cdot 360$ & $5 \cdot 16$ & 70 & $20 \cdot 7$ & $2 \cdot 0$ & $8 \cdot 4$ & n.d. & $100 \cdot 0$ & $\alpha \alpha / \alpha \alpha$ \\
\hline & T.T.* & $\mathrm{F}, 11$ & $\mathrm{AF}$ & $11 \cdot 0$ & $0 \cdot 390$ & $5 \cdot 69$ & 69 & $19 \cdot 3$ & $2 \cdot 05$ & $10 \cdot 0$ & n.d. & $95 \cdot 3$ & $\alpha \alpha / \alpha \alpha$ \\
\hline & Te.T.* & F, 9 & $\mathrm{AF}$ & $11 \cdot 6$ & 0.375 & $5 \cdot 77$ & 65 & $20 \cdot 1$ & $1 \cdot 8$ & $11 \cdot 1$ & n.d. & $96 \cdot 4$ & $\alpha \alpha / \alpha \alpha$ \\
\hline $\mathrm{L}$ & I.L.* & M, $20+$ & $\mathrm{AF}$ & $14 \cdot 5$ & 0.475 & $5 \cdot 72$ & 74 & $25 \cdot 3$ & $2 \cdot 6$ & $11 \cdot 9$ & $1 \cdot 18$ & $100 \cdot 0$ & $\alpha \alpha / \alpha \alpha$ \\
\hline
\end{tabular}

${ }^{*}$ The $\left({ }^{\mathrm{A}} \gamma \delta \beta\right)^{\circ}$-thalassaemia was identified in this person through analysis of the DNA. 
microcytosis and unbalanced globin synthesis. Seven relatives were also heterozygous for $\mathrm{Hb}$ $\mathrm{S}$ and produced no normal $\mathrm{Hb} \mathrm{A}$. Some data on members of three families have been presented before, namely for families $\mathrm{A}$ and $\mathrm{L}$, both being previously classified as having

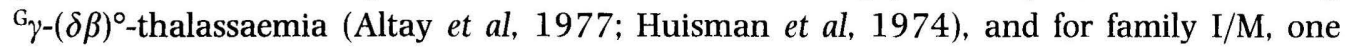
member of which was considered to have a ${ }^{\mathrm{G}} \gamma$ - $\beta^{\circ}$-HPFH (Altay et al, 1977; this person did not participate in the present study). The molecular defect, to be discussed below, was determined for at least one (and often several) member(s) of each of the 10 families presented in the table.

All 24 simple heterozygotes were healthy with only mild haematological abnormalities, notably a mild anaemia among older women and a microcytosis which varied greatly from one person to another (see Table I). The MCV and MCH values were nearly normal for members of the I/M, T and $\mathrm{G}$ families, whereas a marked microcytosis was observed in several other patients. The $\mathrm{Hb} \mathrm{A}_{2}$ values were on the lower side of normal (average 2.3\%) while the $\mathrm{Hb} F$ level $\left(\% \mathrm{~F}_{\mathrm{AD}}\right)$ varied from $4.0 \%$ to $16 \cdot 5 \%$ (average $\left.11 \cdot 2 \%\right)$. Several subjects have been studied repeatedly and those with low $\mathrm{Hb} F$ percentages (W.C.C. and J.L.C. of the M/C family) consistently had low values. The $\%^{\mathrm{G}} \gamma$ in the $\mathrm{Hb} \mathrm{F}$ of the 24 heterozygotes ranged from $86 \cdot 1 \%$ to $100 \%$ (average $93 \cdot 2 \%$ ). The difference between the values observed and the expected $100 \%$ may be due to contribution from the ${ }^{\mathrm{A}} \gamma$ globin gene in trans.

The seven heterozygotes who also inherited $\mathrm{Hb} \mathrm{S}$ have the $\mathrm{Hb} \mathrm{S}-\left({ }^{\mathrm{A}} \gamma \delta \beta\right)^{\circ}$-thalassaemia condition which is associated with a haematologically and clinically mild variant of sickle cell disease. One of these patients, B.W. of family $W$, had an associated $\alpha$-thal-2 heterozygosity. Apart from a lower $\alpha /$ non- $\alpha$ value (see below) her haematological values and $\mathrm{Hb}$ composition data were not different from those of the six other patients. Their $\mathrm{Hb}$ levels ranged from $9 \cdot 2$ to $12 \cdot 8 \mathrm{~g} / \mathrm{dl}$ and the $\mathrm{MCV}$ varied from 71 to $91 \mathrm{fl}$. The average $\mathrm{Hb} \mathrm{A}_{2}$ value was $2 \cdot 3 \%$. The leve: of fetal $\mathrm{Hb}$ (average 19.2\%) were higher than those of the heterozygotes without $\mathrm{Hb} \mathrm{S}$, but the $\mathrm{G}_{\gamma}$ value of $93 \cdot 1 \%$ was approximately the same.

In vitro synthesis data were obtained on three AF patients with the $\alpha \alpha / \alpha \alpha$ genotype who had an average $\alpha /$ non- $\alpha$ value of 1.50 (range 1.25-1.93); seven AF patients with the $-\alpha / \alpha \alpha$ genotype who had an average $\alpha /$ non- $\alpha$ value of 1.31 (range 0.81-1.73); three SF patients with the $\alpha \alpha / \alpha \alpha$ genotype who had an average $\alpha /$ non- $\alpha$ value of 1.85 (range $1.71-1.93$ ) and one SF patient with the $-\alpha / \alpha \alpha$ genotype who had an $\alpha /$ non- $\alpha$ value of 0.88 .

\section{Detailed mapping of the deletion in patient B.A.}

DNA samples from peripheral blood lymphocytes of B.A. (family A) and from a normal fibroblast culture were digested with various restriction enzymes and analysed by agarose gel electrophoresis. Blot hybridization studies employed either a $\gamma$ IVS II probe $(\gamma I V S)$ or a probe for the region $17 \mathrm{kbp} 3^{\prime}$ to the $\beta$ gene (pRK28). Representative autoradiograms for the $\gamma \mathrm{IVS}$ probe are shown in Fig 1. Band sizes obtained with both probes are given in Table II. The patient's DNA showed normal-size bands of normal intensity (from both the affected and normal chromosomes) and of half intensity (from the normal chromosome only), as well as bands of abnormal sizes (from the affected chromosome only).

These data permit the derivation of a map of restriction sites in the $\gamma$-gene region of the $\left({ }^{\mathrm{A}} \gamma \delta \beta\right)^{\circ}$-thalassaemia chromosome, if one assumes a simple deletion and not other 


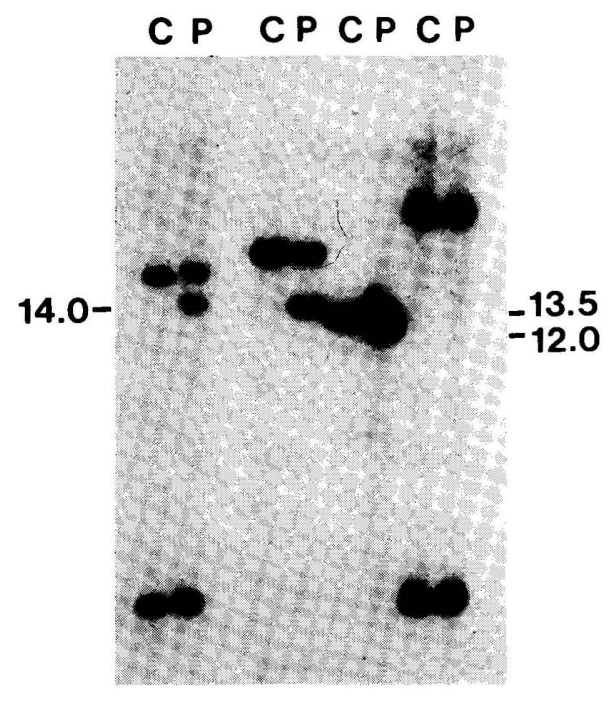

B Bc Bg Hp

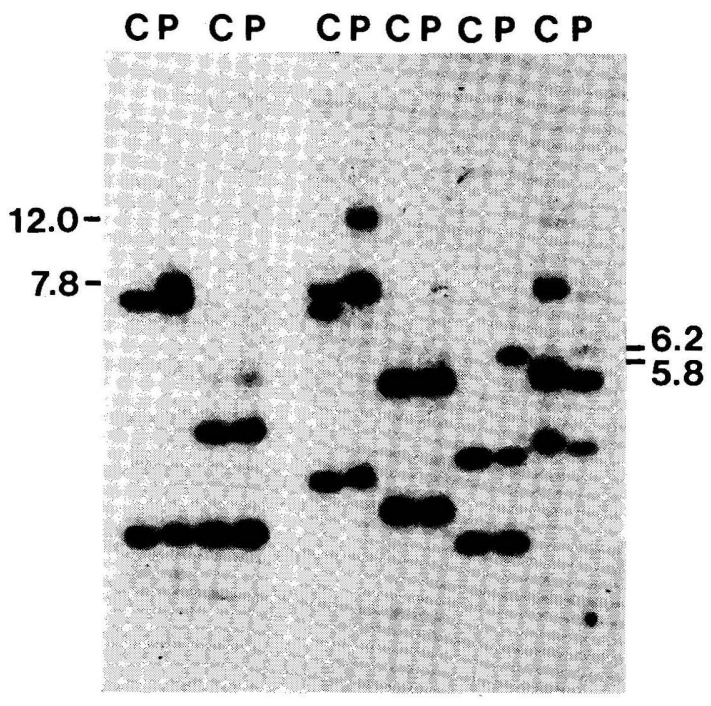

E Hc $\mathrm{Hd} \mathrm{Bg} S \mathrm{~S}$

Fig 1. Autoradiograms from genomic mapping of total DNA. 'C' is DNA from a normal fibroblast cell line and ' $\mathrm{P}$ ' is DNA prepared from whole blood of the affected patient B.A. The $\gamma$ IVS2 probe was used while the restriction enzymes are indicated below the lanes. The sizes of the new bands appearing in the digests of the DNA from the patient are indicated in $\mathrm{kbp}$.

)

chromosomal arrangements. For example, the presence of abnormal-size fragments detected with the $\gamma$ IVS probe for Bam HI, Bgl II, Eco RI, Hind III, Sst I, Bcl I and Xba I shows that the following sites are absent in the affected chromosome: the Bam HI site in the $\delta$-globin gene, the Bgl II site $6 \mathrm{kbp} 3^{\prime}$ of ${ }^{\mathrm{A}} \gamma$, the Eco RI site in exon 3 of ${ }^{\mathrm{A}} \gamma$, the Hind III site $1 \mathrm{kbp} 3^{\prime}$ to ${ }^{\mathrm{A}} \gamma$, the Sst I site in exon 3 of ${ }^{\mathrm{A}} \gamma$, the Bcl I site $3^{\prime}$ to ${ }^{\mathrm{A}} \gamma$, and the Xba I site $7.5 \mathrm{kbp} 3^{\prime}$ to ${ }^{\mathrm{A}} \gamma$. All other sites are intact, as shown by the presence of normal-size fragments.

Fig 2 shows this map for the affected chromosome (Fig 2c), which includes data obtained using the cloned abnormal $7 \cdot 8 \mathrm{kbp}$ Eco RI fragment from this chromosome. Also shown are the maps of the normal chromosome in the $\gamma$-gene region (Fig $2 \mathrm{~b}$ ) and in the region $3^{\prime}$ to the $\beta$-gene (Fig $2 \mathrm{~d}$ ). A comparison of the map of the affected and normal chromosomes localizes the $5^{\prime}$ end of the rearrangement to between the Hpa I site in IVS II of ${ }^{A} \gamma$ (which is intact in B.A.) and the Sst I site in exon 3 of ${ }^{\mathrm{A}} \gamma$ (which is absent in B.A.). Note that this argument assumes that the Sst $\mathrm{I}$ is deleted in the affected chromosome and not absent merely as the result of genetic polymorphism.

The location of the $3^{\prime}$ end of the deletion is suggested by the fact that the map of the affected chromosome shows an arrangement of restriction enzyme sites similar to that found within the $11 \mathrm{kbp}$ Eco RI fragment which lies $5 \mathrm{kbp} 3$ ' to the $\beta$-globin gene (Kaufman et al, 1980 ). This is indicated by data obtained with the $\gamma \mathrm{IVS}$ and the pRK28 probes, as both detected the same abnormal fragments for Eco RI, Bam HI, Hind III and Xba I (Table II); these data also show that the deletion in the affected chromosome lies entirely within the region 
a. $\beta$-Globin Cluster

b. Normal $5^{\circ}$ DNA

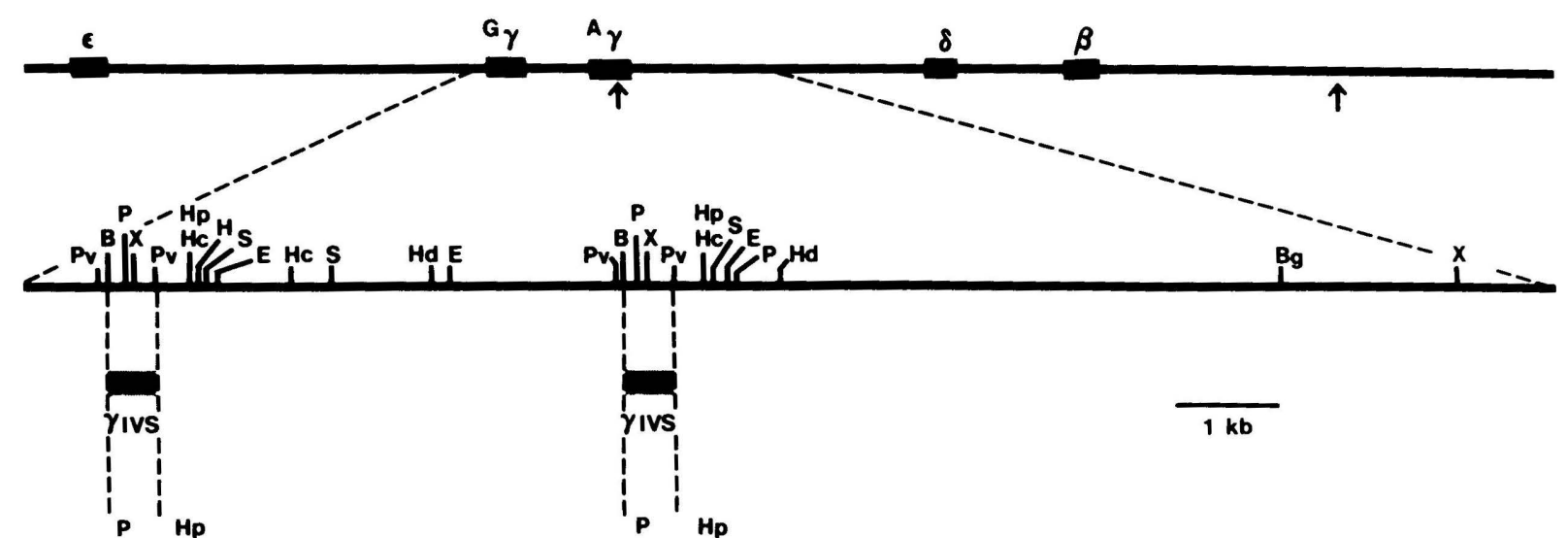

C. Deletion

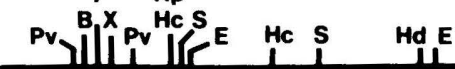

d. Normal $3^{\circ}$ DNA

e. $\beta$-Globin Cluster

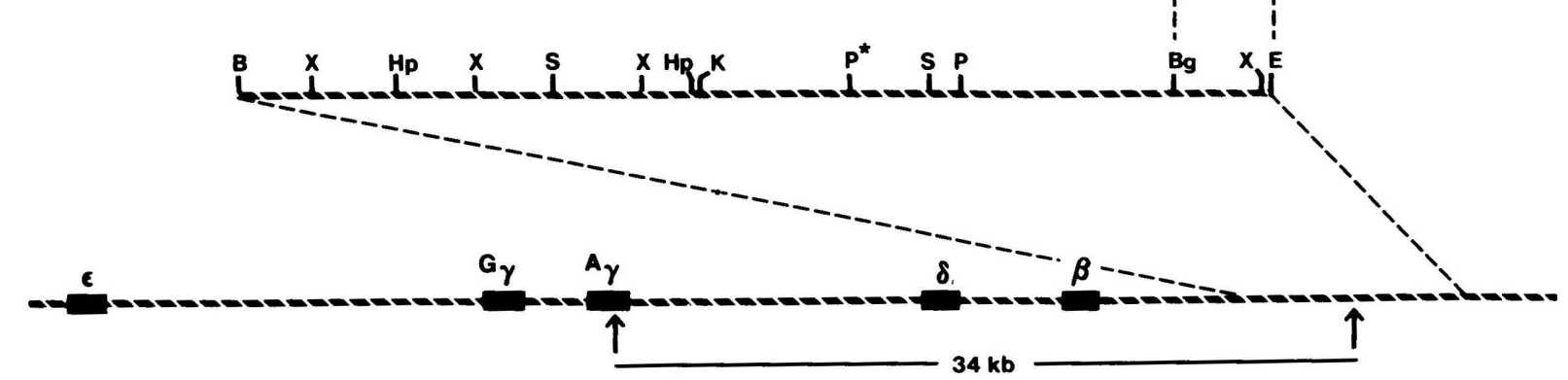


Table II. Fragment sizes from genomic mapping of control and affected (patient B.A.) DNA using the probes $\gamma$ IVS and pRK28. Sizes are in kbp.

\begin{tabular}{|c|c|c|c|c|}
\hline \multirow{2}{*}{$\begin{array}{c}\text { Restriction } \\
\text { enzyme }\end{array}$} & \multicolumn{2}{|c|}{$\gamma$ IVS probe } & \multicolumn{2}{|c|}{ pRK28 probe } \\
\hline & Control & B.A. & B.A. & Control \\
\hline - Bam HI & $16 \cdot 5,5 \cdot 0$ & $(16 \cdot 5), 14 \cdot 0^{*}, 5 \cdot 0$ & $(18 \cdot 0)^{+}, 14 \cdot 0^{*}$ & $27 \cdot 0^{+}$ \\
\hline $\mathrm{Bcl} \mathrm{I}$ & $19 \cdot 0$ & $(19 \cdot 0), 13 \cdot 5$ & $4 \cdot 5,4 \cdot 2$ & $4 \cdot 5,4 \cdot 2$ \\
\hline Bgl II & $13 \cdot 0$ & $(13 \cdot 0), 12 \cdot 0$ & n.d. & n.d. \\
\hline : Eco RI & $7 \cdot 2,2 \cdot 7$ & $7 \cdot 8^{*}, 7 \cdot 2,(2 \cdot 7)$ & $(11 \cdot 0), 7 \cdot 8^{*}$ & $11 \cdot 0$ \\
\hline Hinc II & $4 \cdot 1,2 \cdot 7$ & $4 \cdot 1,2 \cdot 7$ & $5 \cdot 7$ & $5 \cdot 7$ \\
\hline C Hind III & $7 \cdot 7,7 \cdot 2^{+}, 3 \cdot 4$ & $12 \cdot 0^{*}, 7 \cdot 7,(3 \cdot 4)$ & $(17 \cdot 5)^{+}, 12 \cdot 0^{*}$ & $16 \cdot 0$ \\
\hline Hpa I & $24 \cdot 0,5 \cdot 0$ & $24 \cdot 0,5 \cdot 0$ & $25 \cdot 5$ & $25 \cdot 5$ \\
\hline \multicolumn{5}{|l|}{ Hpa I- } \\
\hline Bgl II & $5 \cdot 1,3 \cdot 1$ & $5 \cdot 1,3 \cdot 1$ & $1 \cdot 0$ & $1 \cdot 0$ \\
\hline Pst I & $5 \cdot 0,4 \cdot 0,0 \cdot 9$ & $5 \cdot 0,4 \cdot 0,1 \cdot 9,(0 \cdot 9)$ & n.d. & n.d. \\
\hline Pvu II & 0.5 & 0.5 & n.d. & n.d. \\
\hline Sst I & $3 \cdot 9,2 \cdot 7$ & $5 \cdot 8,(3 \cdot 9), 2 \cdot 7$ & $7 \cdot 2$ & $7 \cdot 2$ \\
\hline 、Xba I & $7 \cdot 9,5 \cdot 4,4 \cdot 1$ & $(7 \cdot 9), 6 \cdot 2^{*}, 5 \cdot 4,4 \cdot 1$ & $6 \cdot 2^{*}$ & $6 \cdot 2$ \\
\hline
\end{tabular}

Values in parentheses indicate a normal fragment which gives a half-intensity band in the affected heterozygous patient. Values in italics indicate a new band in the affected individual. n.d. = not done.

* Bands detected in both probes.

$\uparrow$ Fragments whose size are affected by previously described polymorphic restriction enzyme sites (Jeffreys, 1979; Kan et al, 1980; Tuan et al, 1983).

between the sequences complementary to these two probes in normal DNA (Fig 2). Comparison of Fig 2(c), the map of the affected DNA, to Fig 2(d), the map of normal DNA 3' to the $\beta$-globin gene, allows localization of the $3^{\prime}$ end of the deletion to within $1 \cdot 2 \mathrm{kbp}$ of the Pst I site marked with an asterisk.

Fig 2. (a) A map of the human $\beta$-globin gene cluster, including the linked $\varepsilon,{ }^{\mathrm{G}} \gamma,{ }^{\mathrm{A}} \gamma, \delta$ and $\beta$-globin genes. The vertical arrows below the line indicate the locations of the deletion ends in normal DNA. (b) A restriction enzyme map of a portion of the normal $\beta$-globin cluster-enlarged from the indicated portion of Fig 2(a). These sites are arranged according to previous sequence and mapping data (Shen et al, 1981; Fritsch et al, 1979). The stippled boxes below the line show the $\gamma$ IVS probe used for genomic mapping. Only sites pertinent to the present mapping with this probe are shown. (c) A map of the deletion chromosome. The solid line indicates DNA derived from the $5^{\prime}$ side of the deletion (b above) and the dashed line indicates DNA derived from the $3^{\prime}$ side of the deletion (see line $\mathrm{d}$ below). Sites displayed above the line were derived from genomic mapping data. Sites below the line are additional sites mapped from cloned DNA. (d) A map of a portion of the normal $\beta$-globin cluster-enlarged from the indicated portion of part e of this figure. The stippled box above the line shows the human DNA insert in the plasmid pRK28, which was used as a probe in mapping. The map is derived from mapping of the plasmid pRK20 (Kaufman et al, 1980; Shafit-Zagardo et al, 1982; Henthorn, unpublished data). (e) A map of the human $\beta$-globin gene cluster, including the linked $\varepsilon,{ }^{\mathrm{G}} \gamma,{ }^{\mathrm{A}} \gamma, \delta$ and $\beta$-globin genes. The vertical arrows below the line show the locations of the deletion ends in normal DNA. The $34 \mathrm{kbp}$ of DNA between these arrows has been deleted in affected (deletion) chromosomes. 
In comparing these maps we note that there is a Kpn I site in the normal DNA which is not present in the affected chromosome. All other mapped sites on the $3^{\prime}$ side of the Kpn I site in normal DNA are also present in the affected DNA. By aligning these remaining restriction sites of the affected DNA with the sites in the $3^{\prime}$ portion of normal DNA, a more precise location of the $3^{\prime}$ end of the deletion can be determined. It is within approximately $200 \mathrm{bp}$, but on the 3' side of the Kpn I site. The argument for this localization is as follows. We determined above that the $5^{\prime}$ end of the deletion is located between Hpa I and Sst I sites in the ${ }^{A} \gamma$ gene. These sites are separated by only $62 \mathrm{bp}$ of DNA. In the deleted chromosome the DNA beyond $62 \mathrm{bp}$ on the $3^{\prime}$ side of the Hpa I site must come from the relevant region $3^{\prime}$ to $\beta$. The next $3^{\prime}$ mapped site in the deleted chromosome, that is also present in the normal 3' DNA, is the asterisked Pst I site in Figs 2(c) and 2(d). It is $1.2 \mathrm{kbp}$ from the Hpa I site; therefore approximately $1.1 \mathrm{kbp}(1.2 \mathrm{kbp}$ to $62 \mathrm{bp})$ of DNA in that interval is of $3^{\prime}$ origin. In the normal $3^{\prime}$ DNA the Kpn I site, which is absent in the affected chromosome, is located approximately $1.2 \mathrm{kbp} 5^{\prime}$ to the asterisked Pst I site. Thus, the $3^{\prime}$ end of the deletion is very close to, but on the $3^{\prime}$ side of, the Kpn I site (assuming that its absence in the affected DNA is not due to DNA-sequence polymorphism). We put it within $200 \mathrm{bp}$ so as to allow for measurement errors in mapping and possible polymorphic variation. It is thus estimated that the total amount of DNA deleted in the affected chromosome is $34 \mathrm{kbp}$.

\section{DNA analyses on the additional patients}

DNAs from 19 individuals (shown with asterisks in Table I) were analysed using the restriction enzymes Pst I, Eco RI, Hind III, Hpa I and Bam HI, and the probes $\gamma$ IVS and pRK28. These analyses gave identical band sizes to those of the DNA from patient B.A. (Table II). These results identify an identical deletion of $34 \mathrm{kbp}$ in all 20 subjects whose DNA was analysed and presumably also in the 11 additional affected relatives who are listed in Table I.

Subject I.L. of Table I is unusual in his non-deletion chromosome- he has two ${ }^{\mathrm{G}} \gamma$ genes (and no ${ }^{\mathrm{A}} \gamma$ gene). The relevant evidence is presented in Fig 3. Pst I digestion of DNA from I.L. gave two abnormal-sized fragments after hybridizing to the $\gamma \mathrm{IVS}$ probe. The $1.9 \mathrm{kbp}$ fragment originates from the chromosome with the deletion (Table II), while the $3 \cdot 7 \mathrm{kbp}$ fragment is due to the loss of the Pst I restriction site in the third exon of the $3^{\prime} \gamma$ gene. This situation is characteristic of the ${ }^{\mathrm{G}} \gamma \mathrm{G}_{\gamma}$-chromosomes described by Powers et al (1984).

The number of $\alpha$-globin genes present was determined in 25 subjects. Fourteen had the full complement of four $\alpha$ genes $(\alpha \alpha / \alpha \alpha)$, while 11 had three $\alpha$ genes $(-\alpha / \alpha \alpha)$ corresponding to the $\alpha$-thal-2 heterozygosity. The results for the individual subjects are listed in Table I.

\section{DISCUSSION}

Our study of the DNA of 20 Black individuals previously classified as either ${ }^{\mathrm{G}} \gamma(\delta \beta)^{\circ}$-thal or $\mathrm{G}_{\gamma}(\beta)^{\circ}$-HPFH heterozygotes shows that all 20 (and presumably the 11 relatives with a similar phenotype) had the same genetic defect-a deletion of $34 \mathrm{kbp}$ of DNA. The $5^{\prime}$ end of the deletion is located within 62 bp of DNA between the Hpa I site in the IVS II and the Sst I site in the third exon of the ${ }^{A} \gamma$ globin gene, while the $3^{\prime}$ end is estimated to be within $200 \mathrm{bp}$ of the 


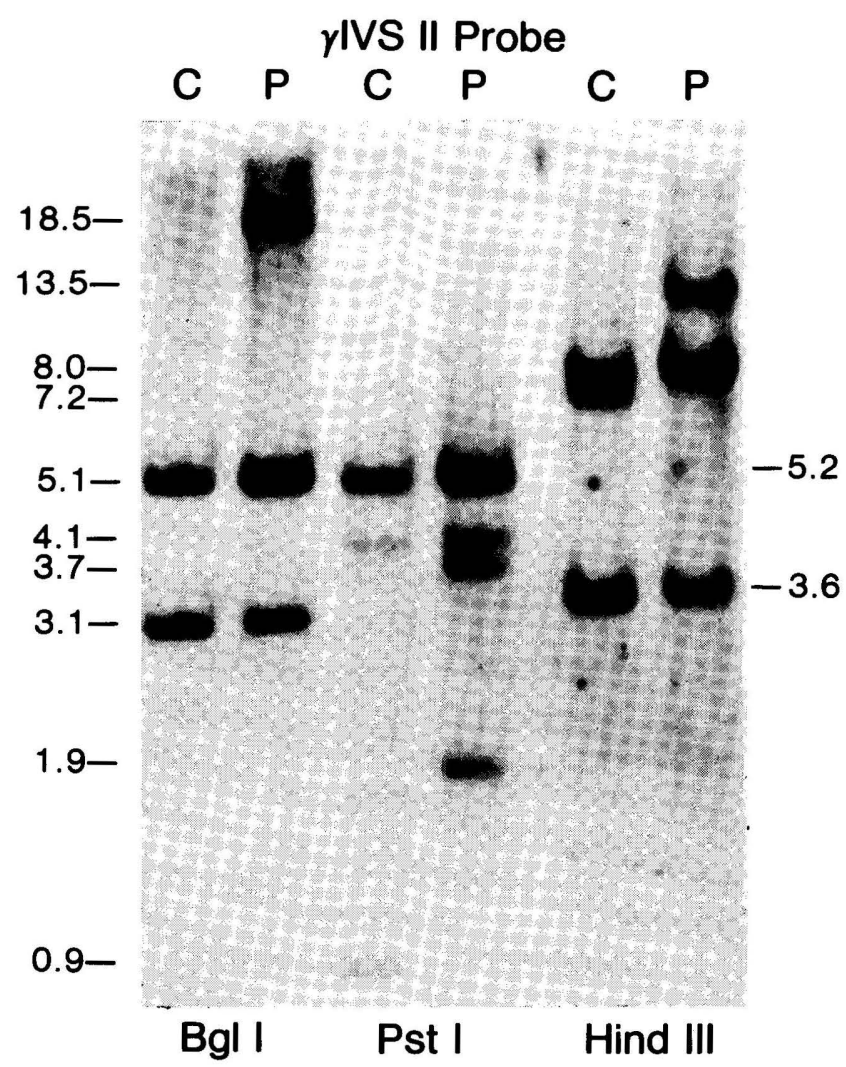

Fig 3. Autoradiogram from genomic mapping of DNA from a normal control person (C) and from an affected individual (P) who is subject I.L. listed in Table III. See text for further details.

Kpn I site, $13 \mathrm{kbp} \mathrm{3'}$ to the $\beta$ globin gene. This large deletion eliminates part of the ${ }^{\mathrm{A}} \gamma-$, and all of the $\psi \beta$-, the $\delta$ - and the $\beta$-globin genes and in heterozygotes leads to a deficiency of the corresponding non- $\alpha$ globin genes. In addition, there is an increase in the synthesis of $\mathrm{G}_{\gamma}$ chains.

Since the deletion is shared by all these individuals and because the heterozygotes for this condition have haematological features compatible with thalassaemia rather than HPFH, we propose that this $34 \mathrm{kbp}$ deletion be described as $\left({ }^{\mathrm{A}} \gamma \delta \beta\right)^{\circ}$-thal. The haematological parameters of this abnormality are heterogeneous but, in most cases, deviate little from normal. These slight deviations may account for previous ambiguities in classification of such persons. Four other deletions resulting in an $\left({ }^{\mathrm{A}} \gamma \delta \beta\right)^{\circ}$-thal condition have been described in Turkey, Malaysia, China and India (Fritsch et al, 1979; Orkin et al, 1979; Jones et al, 1981a, b; Nakatsuji et al, 1984; Trent et al, 1984). The molecular defects of these conditions (reviewed by Trent et al, 1984) are different from the one described here. For instance, the 5' end of the deletion in the Turkish and Malaysian patients was rather close to the $3^{\prime}$ end of the ${ }^{G} \gamma$ gene and thus involved the entire ${ }^{A} \gamma$ gene. The $5^{\prime}$ end of the Chinese deletion is within the ${ }^{\mathrm{A}} \gamma$ gene, like the $5^{\prime}$ end of the deletion described here, but the Chinese deletion is much larger 
Table III. Haematological and haemoglobin composition data in $\mathrm{HPFH}$ and $\delta \beta$-thalassaemia heterozygotes*

\begin{tabular}{|c|c|c|c|c|}
\hline & $\begin{array}{c}\mathrm{G}_{\gamma} \mathrm{A}_{\gamma-\mathrm{HPFH}} \\
(n=54)\end{array}$ & $\begin{array}{l}\mathrm{G}_{\gamma^{\mathrm{A}}} \gamma-\delta \beta \\
(n=62)\end{array}$ & $\begin{array}{c}\mathrm{G}_{\gamma-\delta \beta} \\
(n=27)\end{array}$ & $\begin{array}{c}\left({ }^{\mathrm{A}} \gamma \delta \beta\right)^{\circ} \text {-Thal } \\
(n=24)\end{array}$ \\
\hline $\mathrm{Hb}(\mathrm{g} / \mathrm{dl})$ & $12 \cdot 9 \pm 1 \cdot 6$ & $12 \cdot 2 \pm 1 \cdot 0$ & $12 \cdot 5 \pm 1 \cdot 5$ & $12 \cdot 6 \pm 1 \cdot 5$ \\
\hline $\operatorname{MCV}(\mathrm{fl})$ & $80 \cdot 1 \pm 7 \cdot 3$ & $76 \cdot 7 \pm 6 \cdot 4$ & $76 \cdot 0 \pm 5 \cdot 3$ & $74 \cdot 3 \pm 7 \cdot 3$ \\
\hline $\mathrm{MCH}(\mathrm{pg})$ & $26 \cdot 6 \pm 2 \cdot 7$ & $23 \cdot 4 \pm 2 \cdot 9$ & $24 \cdot 0 \pm 1 \cdot 7$ & $24 \cdot 1 \pm 2 \cdot 7$ \\
\hline $\mathrm{Hb} F(\%)$ & $26 \cdot 3 \pm 4 \cdot 6$ & $10 \cdot 5 \pm 3 \cdot 3$ & $12 \cdot 2 \pm 3 \cdot 1$ & $11 \cdot 2 \pm 3 \cdot 3$ \\
\hline $\mathrm{Hb} \mathrm{A}_{2}(\%)$ & $1 \cdot 9 \pm 0.4$ & $2 \cdot 3 \pm 0 \cdot 5$ & $2 \cdot 2 \pm 0 \cdot 5$ & $2 \cdot 3 \pm 0 \cdot 4$ \\
\hline $\mathrm{G}_{\gamma}$ in $\mathrm{Hb} \mathrm{F}(\%)$ & $41 \pm 5$ & $41 \pm 9$ & $101 \pm 3$ & $93 \cdot 2 \pm 4$ \\
\hline Hb A (pg/cell) & $19 \pm 1 \cdot 7$ & $20 \cdot 4 \pm 2 \cdot 6$ & $20 \cdot 5 \pm 1 \cdot 4$ & $20 \cdot 8 \pm 1 \cdot 9$ \\
\hline $\mathrm{Hb} \mathrm{F}$ (pg/cell) & $7 \cdot 1 \pm 1 \cdot 6$ & $2 \cdot 4 \pm 0 \cdot 8$ & $2 \cdot 9 \pm 0 \cdot 8$ & $2 \cdot 8 \pm 1 \cdot 0$ \\
\hline $\mathrm{Hb} \mathrm{A} \mathrm{A}_{2}(\mathrm{pg} /$ cell $)$ & $0.5 \pm 0.1$ & $0 \cdot 5 \pm 0 \cdot 1$ & $0 \cdot 5 \pm 0 \cdot 1$ & $0.6 \pm 0.1$ \\
\hline $\mathrm{G}_{\gamma}(\mathrm{pg} / \mathrm{cell})$ & $1 \cdot 45$ & 0.49 & 1.45 & $1 \cdot 4$ \\
\hline
\end{tabular}

* Data are from Wood et al (1979) except for those of the last column which are averages and SD of the individual values listed in Table I. The ${ }^{\mathrm{G}} \gamma-\delta \beta$ condition is presently listed as $\left({ }^{\mathrm{A}} \gamma \delta \beta\right)^{\circ}$-thal.

in the $3^{\prime}$ direction (Vanin et al, 1983; Dixie Mager, personal communication). The Indian $\left({ }^{\mathrm{A}} \gamma \delta \beta\right)^{\circ}$-thal patients have a molecular defect involving a complex rearrangement which includes deletions of DNA as well as inversion of the DNA between the ${ }^{\mathrm{A}} \gamma$ and $\delta$ genes (Jones et al, 1981b; Nakatsuji et al, 1984). Despite the apparent differences in the deletion of DNf causing these thalassaemic conditions, the haematological observations among heterozygotes are remarkably similar. Wood et al (1979) summarized such data for $\mathrm{G}^{+}-(\delta \beta)^{\circ}$-thal $\left[=\left({ }^{\mathrm{A}} \gamma \delta \beta\right)^{\circ}\right.$-thal $]$ heterozygotes, and these results are again listed in Table III, together with the average values for our $\left({ }^{\mathrm{A}} \gamma \delta \beta\right)^{\circ}$-thalassaemic heterozygotes. Although the group of ${ }^{\mathrm{G}} \gamma(\delta \beta)^{\circ}$-thalassaemic heterozygotes referred to by Wood et al (1979) may well be a mixture of disorders with different molecular defects, the similarities between these data and those for our $24\left({ }^{A} \gamma \delta \beta\right)^{\circ}$-thal heterozygotes are most striking.

The presence of a $\beta^{\mathrm{S}}$ determinant on the opposite chromosome of some patients in our present study does not greatly affect the haematological parameters, although these compound heterozygotes suffer from a mild form of sickle cell disease. Their MCV (average $80.7 \mathrm{fl}$ ) and $\mathrm{MCH}$ (average $26.9 \mathrm{pg}$ ) values are somewhat higher than seen in the simple heterozygotes (Table I). Most striking is the increased level of $\mathrm{Hb} \mathrm{F}$ (average 19.2\%) which is about double that of simple $\left({ }^{\mathrm{A}} \gamma \delta \beta\right)^{\circ}$ heterozygotes but contains the same level of ${ }^{\mathrm{G}} \gamma$ chain (average $93 \cdot 1 \%$ ). This increase is probably due to a $\mathrm{Hb} \mathrm{F}$ red cell survival which is longer than that of cells containing mainly $\mathrm{Hb} \mathrm{S}$.

The data of Fig 4 show the distribution of $\mathrm{MCV}, \mathrm{MCH}, \% \mathrm{Hb} \mathrm{F}$ and $\%{ }^{\mathrm{G}} \gamma$ values among the $\left({ }^{\mathrm{A}} \gamma \delta \beta\right)^{\circ}$-thalassaemia heterozygotes with or without a $\mathrm{Hb} \mathrm{S}$ or an $\alpha$-thalassaemia-2 heterozygosity. These data suggest that an $\alpha$-thalassaemia-2 heterozygosity $(-\alpha / \alpha \alpha)$ has no consistent or significant effect on the four parameters shown, as well as the additional data given in Table I. 

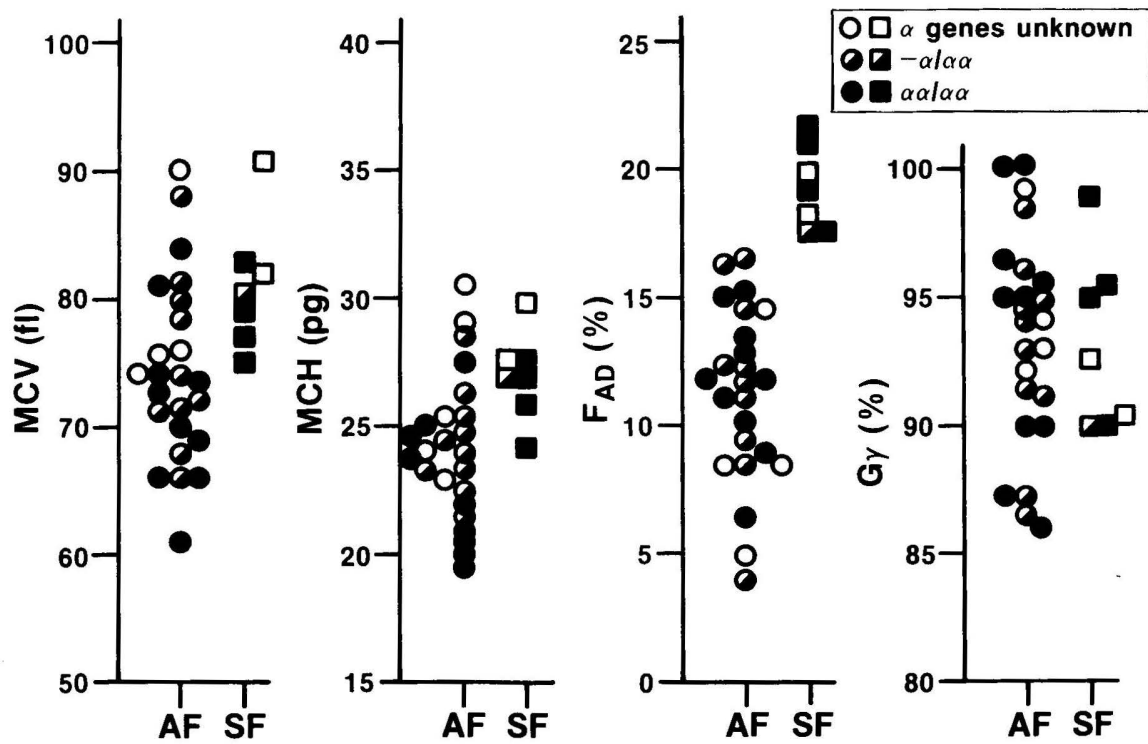

Fig 4. A comparison of some haematological and haemoglobin composition data, listed in Table I. AF refers to the $\left({ }^{\mathrm{A}} \gamma \delta \beta\right)^{\circ}$-thalassaemia heterozygote; $\mathrm{SF}$ to the $\mathrm{Hb} \mathrm{S}-\left({ }^{\mathrm{A}} \gamma \delta \beta\right)^{\circ}$-thalassaemia condition.

Subject I.L., heterozygous for the $\left({ }^{\mathrm{A}} \gamma \delta \beta\right)^{\circ}$-thal chromosome and a variant chromosome laving two ${ }^{\mathrm{G}} \gamma$ globin genes (and no ${ }^{\mathrm{A}} \gamma$ globin gene), is of some special interest. As a consequence of this double heterozygosity, his fetal $\mathrm{Hb}$ does not contain any ${ }^{\mathrm{A}} \gamma$ chains. About $3 \%$ of the Black population is heterozygous for the ${ }^{\mathrm{G}} \gamma^{\mathrm{G}} \gamma$ chromosomal variant and the normal ${ }^{6} \gamma^{A} \gamma$ chromosome (Gilman \& Huisman, 1984), and the detection of a similar chromosome among the 20 Black persons tested is, therefore, not surprising.

We report the characterization of a fifth type of chromosomal alteration in the $\beta$-globin gene cluster responsible for $\left({ }^{\mathrm{A}} \gamma \delta \beta\right)^{\circ}$-thalassaemia. In spite of differences in the molecular nature of the lesion, these all show similar clinical conditions. The molecular tools of DNA analysis are therefore necessary in order to properly differentiate the various $\delta \beta$ thalassaemic disorders present in the human population.

\section{ACKNOWLEDGMENTS}

The authors are indebted to H. F. Harris and B. L. Abraham for their help in the family studies, to Dr Russell E. Kaufman for providing plasmids pRK20 and pRK28, and to Dr John G. Gilman for discussions. These investigations were supported by NIH GM 20069 and AM 20120, by USPHS Research Grants HLB-05168 and HLB-15158, and by designated research funds of the Veterans Administration. This is paper no. 2722 from the Laboratory of Genetics, University of Wisconsin, Madison, WI 53706, and contribution no. 0816 from the Department of Cell and Molecular Biology, Medical College of Georgia, Augusta, GA 30912, U.S.A. 


\section{REFERENCES}

Abraham, E.C., Reese, A., Stallings, M. \& HuisMAN, T.H.J. (1976) Separation of human hemoglobins by DEAE-cellulose chromatography using glycine- $\mathrm{KCN}-\mathrm{NaCl}$ developers. Hemoglobin, 1, 27-44.

Altay, C., Schroeder, W.A. \& Huisman, T.H.J. (1977) The ${ }^{\mathrm{G}} \gamma-\delta \beta$-thalassemia and ${ }^{\mathrm{G}_{\gamma}} \beta^{\circ}$-HPFH conditions in combination with $\beta$-thalassemia and $\mathrm{Hb}$ S. American Journal of Hematology, 3, $1-14$.

Bernards, R., Kooter, J.M. \& Flavell, R.A. (1979) Physical mapping of the globin gene deletion in $(\delta \beta)^{\circ}$-thalassaemia. Gene, 2, 265-280.

Bernards, R. \& Flavell, R.A. (1980) Physical mapping of the globin gene deletion in hereditary persistence of foetal haemoglobin (HPFH). Nucleic Acids Research, 8, 1521-1534.

BetKe, K., Marti, H. \& Schlicht, I. (1959) Estimation of small percentages of foetal haemoglobin. Nature, 184, 1877-1888.

BlattNer, F.R., Blechl, A.E., Denniston-ThompSON, K., FABER, H.E., RichaRds, J.E., SLIGHTOM, J.L., TuCKer, P.W. \& SMithies, O. (1978) Cloning human fetal gamma globin and mouse alpha-type globin DNA: preparation and screening of shotgun collections. Science, 202, 1279-1284.

Boyer, S.H., Margolet, L., Boyer, M.L., Huisman, T.H.J., Schroeder, W.A., WoOD, W.G., WEATHerall, D.J., Clegg, J.B. \& Cartner, R. (1977) Inheritance of $\mathrm{F}$ cell frequency in heterocellular hereditary persistence of fetal hemoglobin: an example of allelic exclusion. American Journal of Human Genetics, 29, 256-271.

Felice, A.E., Özdonmez, R., HeadleE, M.E. \& Huisman, T.H.J. (1982) Organization of $\alpha$ chain genes among $\mathrm{Hb}$ G-Philadelphia heterozygotes in association with $\mathrm{Hb} \mathrm{S}, \beta$-thalassemia and $\alpha$-thalassemia-2. Biochemical Genetics, 20 , 689-701.

Fritsch, E.F., Lawn, R.M. \& Maniatis, T. (1979) Characterisation of deletions which affect the expression of fetal globin genes in man. Nature, 279, 598-603.

Gianni, A.M., Bregni, M., Cappellini, M.D., Fiorelli, G., TARamelli, R., Giglioni, B., Comi, P. \& OTtolenghi, S. (1983) A gene controlling fetal hemoglobin expression in adults is not linked to the non- $\alpha$ globin cluster. The EMBO Journal, 2, 921-925.

Gilman, J.G. \& Huisman, T.H.J. (1984) Two independent genetic factors in the $\beta$ globin gene cluster are associated with high ${ }^{\mathrm{G}} \gamma$ levels in the $\mathrm{Hb}$ F of SS patients. Blood, 64, 452-457.

Gilman, J.G., Huisman, T.H.J. \& Abels, J. (1984) Dutch $\beta^{\circ}$-thalassaemia: a 10 kilobase DNA deletion associated with significant $\gamma$-chain production. British Journal of Haematology, 56, 339-348.

Huisman, T.H.J. \& Jonxis, J.H.P. (1977) The Hemoglobinopathies: Techniques of Identification, Marcell Dekker, New York.

Huisman, T.H.J., Miller, A. \& Schroeder, W.A. (1975) $A^{G} \gamma$ type of the hereditary persistence of fetal hemoglobin with $\beta$ chain production in cis. American Journal of Human Genetics, 27, 765-777.

Huisman, T.H.J., Schroeder, W.A., Efremov, G.D., Duma, H., Mladenovski, B., Hyman, C.B., Rachmilewitz, E.A., Bouver, N., Miller, A., Brodie, A., Shelton, J.R., Shelton, J.B. \& APELl, G. (1974) The present status of the heterogeneity of fetal hemoglobin in $\beta$-thalassemia; an attempt to unify some observations in thalassemia and in related conditions. Annals of the New York Academy of Sciences, 232, 107-124.

Huisman, T.H.J. \& Wilson, J.B. (1980) Recent advances in the quantitation of human fetal hemoglobins with different gamma chains. American Journal of Hematology, 9, 225-235.

JEFFREYS, A.J. (1979) DNA sequence variants in the ${ }^{\mathrm{G}} \gamma_{-},{ }^{\mathrm{A}} \gamma_{-}, \delta$ - and $\beta$-globin genes of man. Cell, $18,1-10$.

Jones, R.W., Old, J.M., Trent, R.J., Clegg, J.B. \& WeAtherall, D.J. (1981a) Restriction mapping of a new deletion responsible for ${ }^{\mathrm{G}} \gamma(\delta \beta)^{\circ}$ thalassemia. Nucleic Acids Research, 9, 6813-6825.

Jones, R.W., Old, J.M., Trent, R.J., Clegg, J.B. \& WeAtherall, D.J. (1981b) Major rearrangement in the human $\beta$-globin gene cluster. Nature, 291, 39-44.

Kan, Y.W., Lee, K.Y., Furbetta, M., Angius, A. \& CAo, A. (1980) Polymorphism of DNA sequence in the $\beta$-globin gene region. Appli- 
cation to prenatal diagnosis of $\beta^{\circ}$ thalassemia in Sardinia. New England Journal of Medicine, 302, 185-188.

Kaufman, R.E., Kretschmer, P.J., Adams, J.W., Coon, H.C., Anderson, W.F. \& Nienhuis, A.W. (1980) Cloning and characterization of DNA sequences surrounding the human $\gamma$-, $\delta$ - and $\beta$-globin genes. Proceedings of the National Academy of Sciences of the United States of America, 77, 4229-4233.

Kutlar, A., Gardiner, M.B., Headlee, M.G., Reese, A.L., Cleek, M.P., Nagle, S., SukuMARAN, P.K. \& Huisman, T.H.J. (1984) Heterogeneity in the molecular basis of three types of hereditary persistence of fetal hemoglobin and the relative synthesis of the ${ }^{\mathrm{G}} \gamma$ and ${ }^{\mathrm{A}} \gamma$ types of $\gamma$ chain. Biochemical Genetics, 22, 21-35.

MaedA, N., Bliska, J.B. \& Smithies, O. (1983) Recombination and balanced chromosome polymorphism suggested by DNA sequences $5^{\prime}$ to the human $\delta$-globin gene. Proceedings of the National Academy of Sciences of the United States of America, 80, 5012-5016.

Mears, J.G., Ramirez, F., Leibowitz, D., NAKamura, F., Bloom, A., Konotey-Ahulu, F. \& BANK, A. (1978) Changes in restricted human cellular DNA fragments containing globin gene sequences in thalassemias and related disorders. Proceedings of the National Academy of Sciences of the United States of America, 75, 1222-1226.

Nakatsuji, T., Gilman, J.G., Sukumaran, P.K. \& Huisman, T.H.J. (1984) Restriction endonuclease gene mapping studies of an Indian $\left({ }^{A} \gamma \delta \beta\right)^{\circ}$-thalassaemia previously identified as

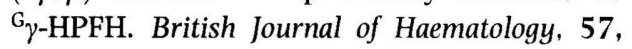
663-670.

Orkin, S.H., Alter, B.P. \& Altay, C. (1979) Deletion of the ${ }^{\mathrm{A}} \gamma$-globin gene in ${ }^{\mathrm{G}} \gamma-\delta \beta$-thalassemia. Journal of Clinical Investigation, 64, 866-869.

Ottolenghi, S., Giglioni, B., Comi, P., Gianni, A.M., Polli, E., Acquaye, C.T.A., Oldham, J.H. \& MASERA, G. (1979) Globin gene deletion in $\mathrm{HPFH}, \delta^{\circ} \beta^{\circ}$ thalassaemia and Hb Lepore disease. Nature, 278, 654-656.

Ottolenghi, S., Giglioni, B., Taramelli, R., Comi, P., Mazza, U., SAglio, G., Camaschella, C., Izzo, P., CaO, A., Galanello, R., Gimferrer, E., Baiget, M. \& Gianni, A.M. (1981) Molecular comparison of $\delta \beta$-thalassemia and heredi- tary persistence of fetal hemoglobin DNAs: evidence of a regulatory area? Proceedings of the National Academy of Sciences of the United States of America, 79, 2347-2351.

Poncz, M., SolowiejczyK, D., Harpel, B., Mory, Y., SchWARTZ, E. \& Surrey, E. (1982) Construction of human gene libraries from small amounts of peripheral blood: analysis of $\beta$-like globin genes. Hemoglobin, 6, 27-36.

Powers, P., Altay, C., Huisman, T.H.J. \& SMithiEs, O. (1984) Two novel arrangements of the human fetal globin genes: ${ }^{G_{\gamma}}{ }^{G_{\gamma}} \gamma$ and ${ }^{\mathrm{A}}{ }_{\gamma-}{ }^{\mathrm{A}} \gamma$. Nucleic Acids Research, submitted.

Schleider, C.T.H., Mayson, S.M. \& Huisman, T.H.J. (1977) Further modification of the microchromatographic determination of Hemoglobin $A_{2}$. Hemoglobin, 1, 503-504.

Schroeder, W.A. \& Huisman, T.H.J. (1980) The Chromatography of Hemoglobin. Marcel Dekker, New York.

Shafit-Zagardo, B., Brown, F.L., Maio, J.J. \& Adams, J.W. (1982) Kpn I families of long, interspersed repetitive DNAs associated with the human $\beta$-globin gene cluster. Gene, 20, 397-407.

Shen, S., Slightom, J.L. \& Smithies, O. (1981) A history of the human fetal globin gene duplication. Cell, 26, 191-203.

Trent, R.J., Jones, R.W., Clegg, J.B., Weatherall, D.J., DAvidson, R. \& Wood, W.G. $(1984)\left({ }^{A} \gamma \delta \beta\right)^{\circ}$ thalassaemia: similarity of phenotype in four different molecular defects, including one newly described. British Journal of Haematology. 57, 279-289.

Tuan, D., Biro, P.A., DeRiel, J.K., Lazarus, H. \& FoRGET, B.G. (1979) Restriction endonuclease mapping of the human $\gamma$ globin gene loci. Nucleic Acids Research, 6, 2519-2544.

Tuan, D., Feingold, E., Newman, M., Weissman, S.M. \& ForgET, B.G. (1983) Different endpoints of deletions causing $\delta \beta$-thalassemia and hereditary persistence of fetal hemoglobin: Implications for the control of $\gamma$-globin gene expression in man. Proceedings of the National Academy of Sciences of the United States of America, 80, 6937-6941.

Tuan, D., Murnane, M.J., deRiel, J.K. \& Forget, B.G. (1980) Heterogeneity in the molecular basis of hereditary persistence of fetal haemoglobin. Nature, 285, 335-337.

Vanin, E.F., Henthorn, P.S., Koussis, D., Gros- 
VELD, F. \& SMITHIES, O. (1983) Unexpected relationships between four large deletions in the human $\beta$-globin gene cluster. Cell, 35, 701-709.

WeAtherall, D.J. \& Clegg, J.B. (1981) The Thalassaemia Syndromes, 3rd edn. Blackwell Scientific Publications, Oxford.
Wood, W.G., Clegg, J.B. \& Weatherall, D.J. (1979) Hereditary persistence of fetal haemoglobin (HPFH) and $\delta \beta$ thalassaemia. British Journal of Haematology, 43, 509-520. 